\title{
Correlation of Width of Anterior Maxillary Teeth with the Intercanine Distance, Distance from Inner to Outer Canthus of Right Eye and Width of First Three Fingers of Right Hand for Teeth Selection
}

\author{
Research Article
}

\author{
Madhura Deshmukh ${ }^{1}$, Subhabrata Maiti² ${ }^{*}$ Dhanraj Ganapathy ${ }^{3}$
}

${ }^{1}$ Department of Prosthodontics and Implantology, Saveetha Dental College and Hospitals, Saveetha Institute of Medical and Technical Sciences Saveetha University, Chennai-600077, Tamilnadu, India.

${ }^{2}$ Assistant Professor, Department of Prosthodontics and Implantology, Saveetha Dental College And Hospitals, Saveetha Institute Of Medical And Technical Sciences, Saveetha University, Chennai-600077, Tamilnadu, India.

${ }^{3}$ Professor and Head, Department of Prosthodontics and Implantology, Saveetha Dental College and Hospitals, Saveetha Institute of Medical and Technical Sciences Saveetha University, Chennai-600077, Tamilnadu, India.

\section{Abstract}

\begin{abstract}
The needs of patients undergoing complete denture treatment for oral health and esthetics are growing, as are their demands for function and comfort. Previously various anthropometric measurements have been suggested for selecting the size of the anterior teeth like inter-alar distance, inter-pupillary distance, intercanthal distance, bi-zygomatic width, intercanine width but the most reliable indicator to determine it remains unclear. The purpose of this study was to evaluate width of anterior maxillary teeth with width of intercanine distance, distance from inner canthus to outer canthus of right eye, and combined width of three fingers of right hand. A total of 50 patients were assessed and reviewed with the usage of digital vernier calliper. The results of comparison of mean differences among three variables Intercanine distance, eye width and combined finger width was done using one way ANOVA test was done. In males, df : 2, F: 11.578, $\mathrm{p}$-value: $0.001(\mathrm{p}<0.05)$ values were obtained which implies statistical significance. In females, df:, F: value ,p-value: $0.004(\mathrm{p}<0.05)$ values were obtained which implies statistical significance. The Pearson correlation coefficient values for variables were Intercanine distance $\times$ Eye width: $0.607^{* *}$, Eye width $\times$ Finger width: $0.657^{* *}$ and Finger width $\times$ Intercanine distance: $0.856^{* *}$ which implies strong correlation. It was concluded that there is a significant correlation between intercanine distance and combined width of the first three fingers of the right hand and statistical significant difference between intercanine distance and inner to outer distance of right eye.
\end{abstract}

Keywords: Esthetics; Anterior Teeth Selection; Intercanine Distance; Eye Width; Combined Finger Width; Dental Esthetics.

\section{Introduction}

The primary consideration for patients seeking prosthodontic treatment is esthetics. The size, colour, morphology and arrangement of the anterior teeth are the various factors which play an imperative role in achieving excellent esthetics in complete denture [1]. The esthetic restoration of the edentulous patient has an important psychological effect on the edentulous patient [2].

Patients receiving their first set of dentures often have expectations to mimic their natural teeth. Therefore, the correct selection of the artificial teeth, especially the anterior teeth selection has effects on the esthetic outcome. Selection of proper anterior teeth size for edentulous patients can be difficult without any pre-extraction records availability. In addition, the generation approaching 70 years of age recognizes that maintaining their natural dentition improves appearance and smile and serves as a visible sign of successful aging [3].

Complete denture patients require comfort as their first priority followed by harmonious appearance and functioning. Also, they often expect to appear similar to when they had their natural teeth especially when receiving the first denture set. Thus, correct selection of artificial teeth is essential to achieve a pleasant esthetic outcome $[4,5]$.

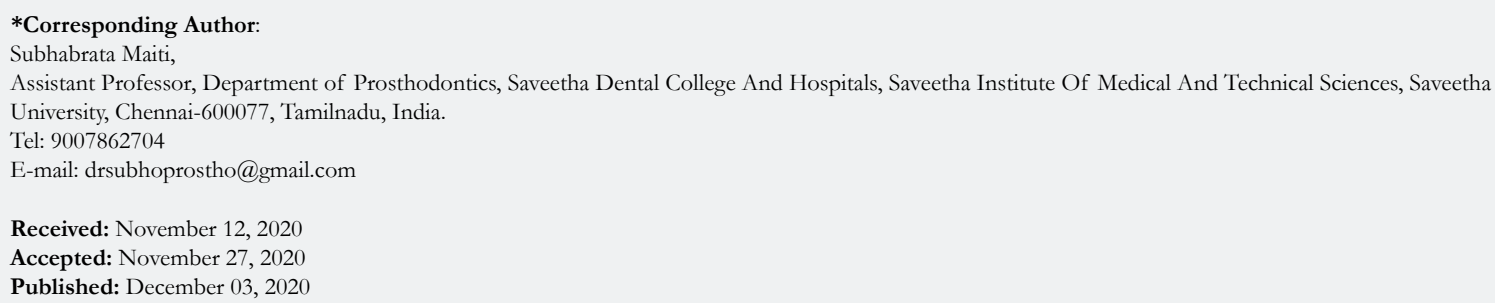

Received: November 12, 2020

Accepted: November 27, 2020

Published: December 03, 2020

Citation: Madhura Deshmukh, Subhabrata Maiti, Dhanraj Ganapathy. Correlation of Width of Anterior Maxillary Teeth with the Intercanine Distance, Distance from Inner to Outer Canthus of Right Eye and Width of First Three Fingers of Right Hand for Teeth Selection. Int J Dentistry Oral Sci. 2020;S5:02:008:39-45.

doi: http://dx.doi.org/10.19070/2377-8075-SI02-05008

Copyright: Subhabrata Maiti ${ }^{\circ} 020$. This is an open-access article distributed under the terms of the Creative Commons Attribution License, which permits unrestricted use, distribution and reproduction in any medium, provided the original author and source are credited. 
The size and form of the maxillary anterior teeth are important for facial esthetics as well as dental esthetics. The goal is to restore the maxillary anterior teeth in harmony with the facial appearance. To determine the dimensions of maxillary anterior teeth, knowledge and understanding of a number of physical and biological factors is necessary which is directly related to each patient as an individual $[6,7]$.

Many attempts have been made to quantify the selection of anterior teeth for complete dentures, but little consensus on an effective method has been reached. Several anatomic measurements, including bizygomatic width (BZW), interpupillary distance (IPD) $[8,9]$ interalar width (IAW) [10-12], inter canthal distance (ICD) [13-15], and intercommissural width (ICW) [16-18] have been suggested to aid in the estimation of a combined width of the maxillary anterior teeth (intercanine width) [19-22].

Esposito reviewed several methods of tooth size selection but felt that selection of the proper size was a subjective decision that the dentist must make, and that every available aid should be used as a consideration in the selection process [23]. Scandrett et al., the best model of predictor variables took into account interalar width, intercommissural width, age, and inner buccal frenum distance [7]. In 1914 Williams et al., found a relationship between the size of faces and the size of teeth [24]. Pound et al., determined face width by measuring the distance from zygoma to zygoma [25].

Previously our department has published extensive research on various aspects of prosthetic dentistry [26-36], this vast research experience has inspired us to research about comparative evaluation of width of anterior maxillary teeth with the intercanine distance, distance from inner to outer canthus of right eye and width of first three fingers of right hand.

The purpose of this study was to predict the width of the maxillary anterior teeth in comparison with factors such as intercanine distance, inner canthus to outer canthus of right eye, and width of three fingers of right hand.

\section{Material and Method}

The patients reported to the Dept of Prosthodontics, Saveetha Dental College, Chennai, participated in this study. A total of 50 people were taken for this study and were divided into two groups - Group1: Males Group2: Females.

The inclusion criteria were 1) No missing maxillary or mandibular anterior teeth 2) No gingival or periodontal conditions problem in the anterior teeth 3)no interdental spacing or crowding; 4) No anterior restoration; and 5) No history of orthodontic treatment. The exclusion criteria were 1) dental malocclusion 2) supra-erupted teeth 3) altered passive eruption 4) developmental anomalies 5) anodontia 6) apparent loss of tooth structure due to attrition, fracture, caries, or restorations.

The measurements taken were intercanine distance (Figure 1), distance from inner to outer canthus of right eye (Figure 2) and width of the first three fingers of the right hand(Figure 3). For all

Figure 1. Measurement of distance from inner to outer canthus of the right eye.

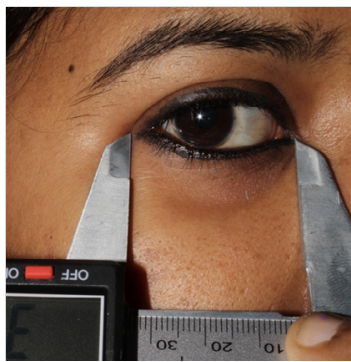

Figure 2. Measurement of combined width of first three fingers of right hand.

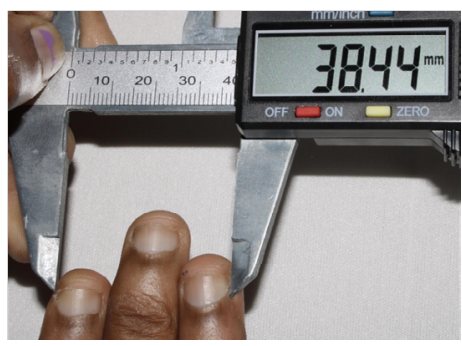

Figure 3. Measurement of width of intercanine distance of maxillary anterior teeth.

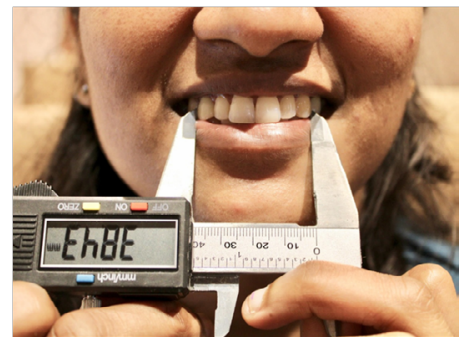


the measurements, a digital vernier caliper was used. Data collection was done with IBM SPSS software and tabulated in MS Excel $^{\text {TM }}$ (Microsoft Office, USA). Statistical analysis was done using SPSS Statistics Software for windows, version 20.0.

The output variables measured were 1)Intercanine distance of maxillary teeth 2) Distance from inner to outer canthus of right eye and 3) Width of the first three fingers of the right hand. One way ANOVA test was used as the statistical test for the study.

\section{Results}

The results were obtained after statistical analysis. Comparison of mean differences among three variables Intercanine distance, eye width and combined finger width (measurement in $\mathrm{mm}$ ) was done using one way ANOVA test (Table 1). In males, the values of Mean \pm SD were Intercanine distance $40.510 \pm 1.954$, eye width $37.969 \pm 2.37$ and combined finger width $40.397 \pm 1.969$ and df: 2, F: 11.578, p-value : 0.001 ( $p<0.05)$ were obtained which implies statistical significance. In females, the values of Mean \pm SD were Intercanine distance $37.450 \pm 1.787$, eye width 35.692 \pm 1.918 and combined finger width $36.978 \pm 1.907$ and df:, $F$ : value , $\mathrm{p}$-value: $0.004(\mathrm{p}<0.05)$ were obtained which implies statistical significance. A bar graph showing mean values for three variables intercanine distance, eyewidth and combined finger width amongst males and females (Figure 4). The Pearson correlation coefficient values for variables were Intercanine distance $\times$ Eye width: $0.607^{* *}$, Eye width $\times$ Finger width: $0.657^{* *}$ and Finger width $\times$ Intercanine distance: $0.856^{* *}$. According to its interpretation, these values lie between \pm 0.50 and \pm 1 which implies strong correlation (Table 2).

\section{Discussion}

In case of pre-extraction records, selection of upper anterior artificial teeth for complete denture patients is difficult. A universally accepted method for accurate determination of mesiodistal width of upper anterior, artificial teeth has not yet been found. In this present study, 25 males and 25 females were evaluated and variables were measured. The results of one way ANOVA test showed that there is significant correlation between inter-canine distance and combined width of the first three fingers of the right hand and statistically significant difference between inter-canine distance and width of inner to outer canthus of the right eye. Thus, for maxillary anterior teeth selection these parameters can be used. The Pearson correlation coefficient was done for three variables intercanine distance, eye width and combined finger width and the values were between \pm 0.50 and \pm 1 which imply strong correlation. The value for correlation of intercanine distance and finger width was more inclined towards 1 and thus has a stronger correlation. Thus, finger width can be used as a parameter in maxillary anterior teeth selection.

Table 1. Comparison of mean difference among three groups- Intercanine distance, eye width and combined finger width (measurement in $\mathrm{mm}$ ).

\begin{tabular}{|c|c|c|c|c|c|c|c|c|}
\hline \multicolumn{8}{|c|}{ ANOVA } & \multirow{3}{*}{ p-value } \\
\hline & & \multirow{2}{*}{ Mean \pm SD } & \multirow{2}{*}{ Standard Error } & \multicolumn{2}{|c|}{$95 \%$ confidence interval } & \multirow{3}{*}{ df } & \multirow{3}{*}{$\mathbf{F}$} & \\
\hline & & & & Lower Bound & Upper Bound & & & \\
\hline \multirow{3}{*}{ MALES } & ICD & $40.510 \pm 1.954$ & 0.39 & 39.704 & 41.317 & & & \\
\hline & Eye Width & $37.969 \pm 2.378$ & 0.475 & 36.987 & 38.95 & \multirow{2}{*}{2} & \multirow{2}{*}{11.578} & \multirow{2}{*}{$0.001 *$} \\
\hline & Finger Width & $40.397 \pm 1.969$ & 0.393 & 39.584 & 41.21 & & & \\
\hline \multirow{3}{*}{ FEMALES } & ICD & $37.450 \pm 1.787$ & 0.357 & 36.712 & 38.187 & \multirow{3}{*}{2} & \multirow{3}{*}{5.904} & \multirow{3}{*}{$0.004 *$} \\
\hline & Eye Width & $35.692 \pm 1.918$ & 0.383 & 34.9 & 36.483 & & & \\
\hline & Finger Width & $36.978 \pm 1.907$ & 0.381 & 36.19 & 37.765 & & & \\
\hline
\end{tabular}

*statistically significant $\mathrm{p}<0.05$

$\mathrm{P}$ value is derived from one-way ANOVA test.

Figure 4. A bar graph showing mean values for three variables intercanine distance, eyewidth and combined finger width amongst males and females.

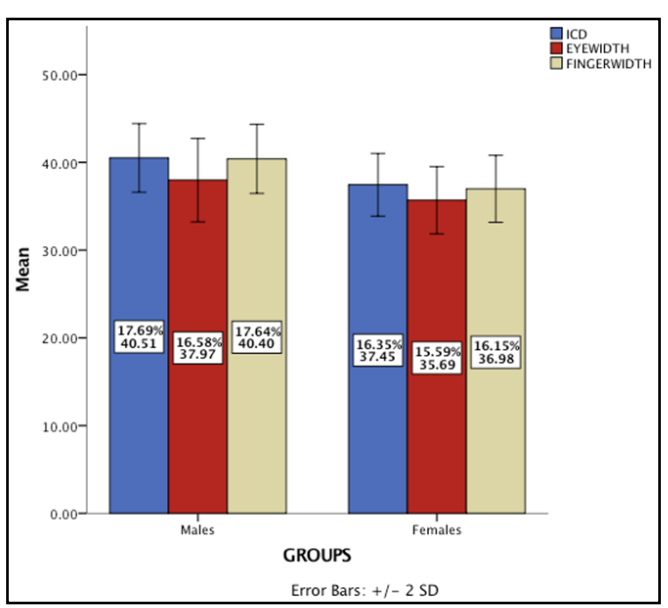


Table 2. Correlation between the eye width and combined finger width groups with mesio distal width of intercanine distance.

\begin{tabular}{|c|c|c|c|c|}
\hline \multicolumn{5}{|c|}{ Correlations } \\
\hline & & ICD & EYE WIDTH & FINGER WIDTH \\
\hline ICD & $\begin{array}{l}\text { Pearson Correlation } \\
\text { Sig. (2-tailed) } \\
\text { Sum of Squares and } \\
\text { Cross-products } \\
\text { Covariance } \\
\text { N }\end{array}$ & $\begin{array}{c}1 \\
285.452 \\
5.826 \\
50\end{array}$ & $\begin{array}{c}.607 * * \\
0 \\
174.239 \\
\\
3.556 \\
50\end{array}$ & $\begin{array}{c}.856^{* *} \\
0 \\
261.401 \\
\\
5.335 \\
50\end{array}$ \\
\hline $\begin{array}{c}\text { EYE } \\
\text { WIDTH }\end{array}$ & $\begin{array}{l}\text { Pearson Correlation } \\
\text { Sig. (2-tailed) } \\
\text { Sum of Squares and } \\
\text { Cross-products } \\
\text { Covariance } \\
\text { N }\end{array}$ & $\begin{array}{c}.607 * * \\
0 \\
174.239 \\
\\
3.556 \\
50\end{array}$ & $\begin{array}{c}1 \\
288.878\end{array}$ & $\begin{array}{c}.657 * * \\
0 \\
201.904 \\
\\
4.12 \\
50\end{array}$ \\
\hline & $\begin{array}{l}\text { Pearson Correlation } \\
\text { Sig. (2-tailed) } \\
\text { Sum of Squares and } \\
\text { Cross-products } \\
\text { Covariance }\end{array}$ & $\begin{array}{c}.856^{* *} \\
0 \\
261.401 \\
5.335 \\
50\end{array}$ & $\begin{array}{c}.657^{* *} \\
0 \\
201.904 \\
4.12 \\
50\end{array}$ & $\begin{array}{c}1 \\
326.652 \\
6.666 \\
50\end{array}$ \\
\hline
\end{tabular}

One of the critical aspects of esthetic dentistry is designing the mathematical proportion to relate successive widths of anterior teeth whereas golden proportion, golden percentage theories have been introduced into the field. In a study by Kern, it was found that $93 \%$ of nasal width was equal to or within $0.5 \mathrm{~mm}$ of four maxillary incisors [37]. Mavroskoufis et al., in 1980 found that inter ala-nasal width is a reliable guide to selecting the mold of anterior teeth and that incisive papilla provides a stable anatomical landmark for arranging the labial surfaces of central incisors at $10 \mathrm{~mm}$ anterior the posterior border of papilla(38). Silverman found that the distal surface of maxillary canines was $\pm 4 \mathrm{~mm}$ from the commissures [39]. Lombardi was first to suggest that application of golden proportion in dentistry. Intercanine distance should be used only as reference value in estimations of central incisor width [40]. Intercanine distance should be used only as reference value in estimations of central incisor width.Final tooth selection for edentulous subjects should be made in accordance with facial form [41]. In a systematic review by Ashish Jain et al, they stated that 1) The anthropometric measurement used depends on the population group which is being used 2) There is no single anthropometric measurement that can be used to determine width of maxillary anterior teeth. 3) In Indian population, a high degree of correlation was seen between inter-alar distance, inter-pupillary distance, bizygomatic width and width of maxillary anterior teeth [42].

The limitation of the study is that the sample size was limited. More conclusive results can be derived from a larger sample size. To summarize the present study, for maxillary anterior teeth selection, both eye width and combined width of the first three fingers showed statistically significant correlation. But to obtain more accurate results, combined width of the first three fingers can be used as a parameter as it showed a stronger correlation with intercanine distance.

\section{Conclusion}

Within the limitation of the study, we concluded that there is a significant correlation between intercanine distance and combined width of the first three fingers of the right hand and statistical significant difference between intercanine distance and inner to outer distance of right eye.

\section{References}

[1]. Krajicek DD. Natural appearance for the individual denture patient. The Journal of Prosthetic Dentistry. 1960 Mar 1; 10(2): 205-14.

[2]. Ahila SC, Vaishnavi P, Muthu Kumar B. Comparative evaluation of maxillary and mandibular anterior teeth width with the length of index and little finger. J Indian Prosthodont Soc. 2014 Sep; 14(3): 215-8. Pubmed PMID: 25183904.

[3]. Wulfman C, du Montcel ST, Jonas P, Fattouh J, Rignon-Bret C. Aesthetic demand of French seniors: a large-scale study. Gerodontology. 2010; 27(4): 266-71. Pubmed PMID: 19619229.

[4]. Deogade SC, Mantri SS, Sumathi K, Rajoriya S. The relationship between innercanthal dimension and interalar width to the intercanine width of maxillary anterior teeth in central Indian population. J Indian Prosthodont Soc. 2015 Apr; 15(2): 91-7. Pubmed PMID: 26929493.

[5]. Strajnić L, Vuletić I, Vucinić P. The significance of biometric parameters in determining anterior teeth width. Vojnosanit Pregl. 2013 Jul; 70(7): 653-9. Pubmed PMID: 23984613.

[6]. Co B. Swenson's complete dentures. St Louis: Mosby. 1970.

[7]. Scandrett FR, Kerber PE, Umrigar ZR. A clinical evaluation of techniques to determine the combined width of the maxillary anterior teeth and the maxillary central incisor. J Prosthet Dent. 1982 Jul; 48(1): 15-22. Pubmed PMID: 6955504.

[8]. Al-el-Sheikh HM, Al-Athel MS. The relationship of interalar width, interpupillary width and maxillary anterior teeth width in Saudi population. Odontostomatol Trop. 1998; 21(84): 7-10. Pubmed PMID: 11372110.

[9]. Hussain MW, Qamar K, Naeem S. THE ROLE OF INTERPUPILLARY DISTANCE IN THE SELECTION OF ANTERIOR TEETH. Pakistan Oral \& Dental Journal. 2012 Jun 1; 32(1).

[10]. Latta GH, Weaver JR, Conkin JE. The relationship between the width of the mouth, interalar width, bizygomatic width, and interpupillary distance in edentulous patients. J Prosthet Dent. 1991 Feb; 65(2): 250-4. Pubmed PMID: 2051360.

[11]. Hoffman W, Bomberg TJ, Hatch RA. Interalar width as a guide in denture 
tooth selection. J Prosthet Dent. 1986 Feb; 55(2): 219-21. Pubmed PMID: 3514860 .

[12]. Varjāo FM, Nogueira SS. Nasal width as a guide for the selection of maxillary complete denture anterior teeth in four racial groups. J Prosthodont. 2006 Nov; 15(6): 353-8. Pubmed PMID: 17096807.

[13]. Tandale UE, Dange SP, Khalikar AN. Biometric relationship between intercanthal dimension and the widths of maxillary anterior teeth. J Indian Prosthodont Soc. 2007 Jul 1; 7(3): 123

[14]. Abdullah MA, Stipho HD, Talic YF, Khan N. The significance of inner canthal distance in prosthodontics. Saudi Dent J. 1997; 9(1): 36-9.

[15]. Patel JR, Sethuraman R, Yg N, Shah MH. A Comparative Evaluation of the Relationship of Inner-Canthal Distance and Inter-Alar Width to the InterCanine Width amongst the Gujarati Population. Journal of Advanced Oral Research. 2011 Oct 1; 2(3): 31-8.

[16]. Sinavarat P, Anunmana C, Hossain S. The relationship of maxillary canines to the facial anatomical landmarks in a group of Thai people. J Adv Prosthodont. 2013 Nov; 5(4): 369-73. Pubmed PMID: 24353872.

[17]. Varjāo FM, Nogueira SS. Intercommissural width in 4 racial groups as a guide for the selection of maxillary anterior teeth in complete dentures. Int $\mathrm{J}$ Prosthodont. 2005 Nov; 18(6): 513-5. Pubmed PMID: 16335171.

[18]. Hussain MW, Qamar K, Naeem S. Significance of intercom missural width and anterior teeth selection. Pak. Oral Dent J. 2013; 33(2): 393-6.

[19]. Al Wazzan KA, Al Haidan A, Al Madi EM, Al Murfarj A. The relationship between facial references and mesiodistal width of maxillary anterior teeth among Saudi patients. Alex Dent J. 1995; 20(4): 39-45.

[20]. Esan TA, Oziegbe OE, Onapokya HO. Facial approximation: evaluation of dental and facial proportions with height. Afr Health Sci. $2012 \mathrm{Mar}$; 12(1): 63-8. Pubmed PMID: 23066422.

[21]. Hossain S, Islam KZ, Islam KM. Correlation between maxillary canines and facial anatomical landmarks in a group of Bangladeshi people. City Dental College Journal. 2012 Oct 21; 9(2): 12-4

[22]. Shetty K, Kumar M, Palagiri K, Amanna S, Shetty S. Facial measurements as predictors of the length of the maxillary central incisor in a cross section of the Indian population-A clinical study. Journal of Oral Hygiene \& Health. 2013; $1-4$

[23]. Esposito SJ. Esthetics for denture patients. J Prosthet Dent. 1980 Dec; 44(6): 608-15. Pubmed PMID: 7003120.

[24]. Williams JL. A new classification of human tooth forms with special reference to a new system of artificial teeth. J Allied Dent Soc. 1914; 9: 1-52.

[25]. Pound E. Personalised denture procedures Anaheim. Denar Corporation, Calif. 1973; 22.

[26]. Anbu RT, Suresh V, Gounder R, Kannan A. Comparison of the Efficacy of Three Different Bone Regeneration Materials: An Animal Study. Eur J Dent. 2019 Feb; 13(1): 22-28. Pubmed PMID: 31170752.

[27]. Ashok V, Ganapathy D. A geometrical method to classify face forms. J Oral Biol Craniofac Res. 2019 Jul; 9(3): 232-235. Pubmed PMID: 31198677.

[28]. Kannan A. Effect of Coated Surfaces influencing Screw Loosening in Implants: A Systematic Review and Meta-analysis. World. 2017 Nov; 8(6):
496-502.

[29]. Ariga P, Narayanan V, Jain AR, Philip JM, Nathan S. Clinical and functional outcomes of implant prostheses in fibula free flaps. World J Dent. 2017; 8: 171-6.

[30]. Jain AR, Nallaswamy D, Ariga P, Ganapathy DM. Determination of correlation of width of maxillary anterior teeth using extraoral and intraoral factors in Indian population: A systematic review. World J Dent. 2018 Jan; 9: 68-75.

[31]. Evaluation of Corrosive Behavior of Four Nickel-chromium Alloys in Artificial Saliva by Cyclic Polarization Test: An in vitro Study. World Journal of Dentistry. 2017; 8(6): 477-82.

[32]. Ranganathan H, Ganapathy DM, Jain AR. Cervical and Incisal Marginal Discrepancy in Ceramic Laminate Veneering Materials: A SEM Analysis. Contemp Clin Dent. 2017 Apr; 8(2): 272-278. Pubmed PMID: 28839415.

[33]. Ashraf J, Jain AR, Ariga P, Nallaswamy D. Prevalence of partial edentulousness and treatment needs in rural population of South India. World J Dent. 2017; 8(3): 213-7.

[34]. Duraisamy R, Krishnan CS, Ramasubramanian H, Sampathkumar J, Mariappan S, Navarasampatti Sivaprakasam A. Compatibility of Nonoriginal Abutments With Implants: Evaluation of Microgap at the Implant-Abutment Interface, With Original and Nonoriginal Abutments. Implant Dent. 2019 Jun; 28(3): 289-95. Pubmed PMID: 31124826.

[35]. Gupta P, Ariga P, Deogade SC. Effect of Monopoly-coating Agent on the Surface Roughness of a Tissue Conditioner Subjected to Cleansing and Disinfection: A Contact Profilometric Study. Contemp Clin Dent. 2018 Jun; 9(Suppl 1): S122-S126. Pubmed PMID: 29962776.

[36]. Varghese SS, Ramesh A, Veeraiyan DN. Blended Module-Based Teaching in Biostatistics and Research Methodology: A Retrospective Study with Postgraduate Dental Students. J Dent Educ. 2019 Apr; 83(4): 445-450. Pubmed PMID: 30745352

[37]. Kern BE. Anthropometric parameters of tooth selection. J Prosthet Dent. 1967 May; 17(5): 431-7. Pubmed PMID: 5228214

[38]. Mavroskoufis F, Ritchie GM. Nasal width and incisive papilla as guides for the selection and arrangement of maxillary anterior teeth. The Journal of Prosthetic Dentistry. 1981; 45(6): 592-7. Pubmed PMID: 6941015.

[39]. Silverman SI. Physiologic factors in complete denture esthetics. Dent Clin North Am. 1967 Mar; 115-22. Pubmed PMID: 5225594.

[40]. Lombardi RE. The principles of visual perception and their clinical application to denture esthetics. J Prosthet Dent. 1973 Apr; 29(4): 358-82. Pubmed PMID: 4570911

[41]. Abdullah MA. Inner canthal distance and geometric progression as a predictor of maxillary central incisor width. J Prosthet Dent. 2002 Jul; 88(1): 16-20. Pubmed PMID: 12239474.

[42]. Jain AR, Nallaswamy D, Ariga P, Ganapathy DM. Determination of correlation of width of maxillary anterior teeth using extraoral and intraoral factors in Indian population: A systematic review. World J Dent. 2018 Jan; 9: 68-75. 